\title{
Удосконалення програмування підготовки кваліфікованих спортсменів у веслуванні
}

\author{
Ольга Русанова
}

Національний університет фізичного виховання і спорту України, Київ, Україна

Анотація. Стаття присвячена питанням розробки, формалізації та алгоритмізації програмування й шляхів його практичної реалізації відповідно до системи управління тренувальними і змагальними навантаженнями спортсменів у веслуванні. Мета. Вивчити стан програмування й шляхи його реалізації у веслуванні. Методи. Аналіз, систематизація та узагальнення даних літературних джерел, метод евристичного моделювання. Результати. Основні теоретичні здобутки та розроблені підходи до програмування (аналітико-системний; програмноцільовий; перспективно прогностичний) посідають важливе місце в арсеналі сучасної теорії та методики спортивної підготовки.

Аргументовано, що система програмування відзначається цілісністю і є складно організованою, ієрархічно впорядкованою сукупністю елементів, поєднаних між собою зв'язками, які є результатом взаємного впливу окремих складових. У системі програмування обгрунтовано шляхи практичного застосування та їі реалізації у процесі підготовки кваліфікованих спортсменів у веслуванні.

Отримані результати дозволили створити алгоритмізовану систему критерій-орієнтованого програмування, що складається з кількох функціональних блоків, а саме: первинний контроль 3 визначенням індивідуальних параметрів тренувальних навантажень, рівня спеціальної роботоздатності та ффункціональної підготовленості спортсмена на певному етапі тренувального процесу; формування тренувальної програми для визначеного періоду з урахуванням індивідуальних параметрів навантаження спортсмена; оцінювання результатів контролю та визначення відповідності отриманих показників модельним; корекція завдань тренувальної програми в разі неповної реалізації програми попереднього періоду. В результаті програма піддається корекції, що найчастіше виражається у доповненні завдань нового періоду невиконаними завданнями попереднього; проведення комплексу тренувальних заходів на основі скоригованої програми; оцінка ефективності застосування розробленої програми, аналізу досягнутих критеріїв. Рух циклу закінчується тоді, коли оцінка результатів контролю відповідає встановленим вимогам.

Ключові слова: програмування, веслування, системний підхід, алгоритм програмування.

\section{Olha Rusanova}

\section{IMPROVEMENT OF PREPARATION PROGRAMING FOR SKILLED ATHLETES IN ROWING}

Abstract. The article addresses the development, formalization and algorithmization of programming and ways of its practical implementation in accordance with the management system of training and competitive loads of athletes in rowing. Objective. To study the state of programming and ways of its realization in rowing. Methods. Analysis, systematization and generalization of data of literature sources, method of heuristic modeling. Results. The main theoretical achievements and developed approaches to programming (analytical-system; program-target; perspective prognostic) occupy an important place in the arsenal of modern theory and methods of sports training.

It is argued that the programming system is characterized by integrity and is a complexly organized, hierarchically ordered set of elements connected by links that are the result of the mutual influence of individual components. The programming system substantiates the ways of practical application and its implementation in the process of training qualified athletes in rowing. The findings allowed to create an algorithm-driven system of criterion-oriented programming, consisting of several functional blocks, namely: initial control with determination of individual parameters of training loads, level of special work capacity and athlete functional fitness at a certain stage of training process; formation of a training program for a certain period with account for the individual parameters of the athlete's load; evaluation of control results and determination of compliance of the obtained indices with the model ones; correction of the tasks of the training program in case of incomplete implementation of the previous period program. As a result, the program is subject to correction, which is often expressed in the addition to the tasks of the new period of unfulfilled tasks of the previous one; conducting a complex of training activities based on the adjusted program; assessment of the effectiveness of the developed program, analysis of the achieved criteria. The movement of the cycle ends when the assessment of control results meets the established requirements.

Keywords: programming, rowing, system approach, programming algorithm.

Rusanova 0. Improvement of preparation programing for skilled athletes in rowing.

Theory and Methods of Physical education and sports. 2020; 3: 43-49

DOI: 10.32652/tmfvs.2020.3.43-49
Русанова О. Удосконалення програмування підготовки кваліфікованих спортсменів у веслуванні. Теорія і методика фрізичного виховання і спорту. 2020; 3: 43-49 DOI: $10.32652 /$ tmfvs.2020.3.43-49
Вступ. Сьогодні сучасна спортивна наука, покликана пояснювати та пропонувати найбільш ефективні варіанти підготовки у спорті вищих досягнень, демонструє неповноту та суперечливість базових концепцій і моделей підготовки, має ряд проблем в обґрунтуванні та прогнозуванні довгострокової траєкторії реалізації можливостей спортсменів у веслуванні.

У цьому сенсі стає зрозумілою зростаюча увага з боку науковців до проблеми концептуального усвідомлення, системного дослідження програмування підготовки спортсменів та формування на цій основі нової концепції управління тренувальними навантаженнями. Питання важливості досліджень програмування підготовки є предметом численних наукових дискусій. Концептуальні положення та теоретичні основи програмування викладено у працях вітчизняних та зарубіжних учених - В. В. Петровського (1973); В. М. Платонова (1986-2015); Ю. В. Верхошанського (1985-1999); А. С. Горлова (1994); В. М. Костюкевича (2018); Guy Haff (2010); M. Buchheit, P. Laursen (2013) та ін.

В узагальненому значенні терміна, програмування передбачає наявність складної системи цілей, кілька відносно самостійних рівнів функціонування і системи контролю, що дозволяє постійно оцінювати ефективність реалізації програм.

Застосування методів програмування у тренувальному процесі спортсменів спостергається протягом останніх десятиліть [1, 2, 5, 7].

Незважаючи на очевидні досягнення спортивної науки в дослідженні окреслених наукових проблем, чимало питань і на сьогодні залишаються недостатньо розкритими й об ґрунтованими у методологічному аспекті, зокрема, у процесі програмування не повністю враховуються вікові, гендерні, кваліфрікаційні та індивідуальні особливості спортсменіввеслувальників, а також спеціалізо- 
вана спрямованість тренувального процесу, обумовлена особливостями енергозабезпечення змагальної діяльності [3, 4, 9, 10, 14].

Відтак постає необхідність концептуального усвідомлення та системного дослідження теоретико-методологічних та аналітичних підходів провідних науковців до еволюції програмування та обґрунтування на цій основі критерій-орієнтованого алгоритму програмування у процесі підготовки кваліфікованих спортсменів. Зазначене також актуалізує потребу виокремлення теоретико-методологічних засад та системного аналізу програмування підготовки кваліфікованих спортсменів, зокрема й у веслуванні.

Дослідження виконували відповідно до теми 2.9 «Побудова тренувального процесу висококваліфікованих спортсменів, які спеціалізуються у водних видах спорту, з урахуванням вимог змагальної діяльності» плану науково-дослідної роботи НУФВСУ на 2016-2020 рр. (номер держреєстрації 0116U001614).

Мета дослідження - обґрунтування, розробка, формалізація та алгоритмізація програмування й шляхів його практичної реалізації відповідно до системи управління тренувальними і змагальними навантаженнями спортсменів у веслуванні на основі застосування системного підходу.

Методи дослідження: аналіз, систематизація та узагальнення даних літературних джерел, метод евристичного моделювання.

Результати дослідження та їх обговорення. Управління тренувальним процесом кваліфрікованих спортсменів здійснюється на основі планування, моделювання та програмування. Планування займає основне місце в ієрархічній структурі управлінських впливів [9].

Програмування спортивного тренування - це планування більш високого рівня. Воно передбачає створення інформаційних банків стандартизованих тренувальних програм, а також розробку цільових завдань та стандартних алгоритмів для здійснення конкретних процедур планування на основі виокремлення структури, типі- зації та моделювання різних за тривалістю циклів тренування [15].

Планування та програмування мають певні протиріччя: чим довший намічений інтервал часу, тим складніше передбачити, якими повинні бути риси цього процесу у дійсності. Повноцінне програмування тренувального процесу є можливим тільки до відносно коротких часових етапів. Таким чином, чим трівалішим $є$ цикл підготовки, тим менш виправдана деталізація планування [13, 15]. Науковометодичними передумовами до планування та програмування процесу підготовки спортсменів $є$ знання про побудову:

- багаторічної системи занять та річних циклів, про особливості розвитку організму людини та індивідуальних особливостей розвитку спортивної форми, про специфічні особли вості довготривалої адаптації до певних видів м'язової діяльності;

- окремих етапів (мезоциклів), про принципові тенденції у динаміці стану спортсмена у зв'язку з опановуваними тренувальними навантаженнями залежно від їхнього змісту, обсягу, інтенсивності та чергування;

- мікроциклів, про форми поєднання найближчих та слідових тренувальних есректів навантажень різної величини та переважної спрямованості [15].

у 1990-х роках реалізовувався аналітико-системний підхід до вдосконалення планування тренування шляхом дослідження і апробації окремих варіантів структури циклів різно тривалості, вивчення ефективност окремих методів тренування, дозування тренувальних навантажень, впливи того чи іншого компонента підготовленості на кінцевий результат. У зв'язку з цим накопичувалася велика кількість наукових даних, на основі яких удосконалювалися окремі елементи планування, але кардинальних змін в цілому не відбувалося. У цей час науково-технічний прогрес поставив на порядок денний принципово нов підходи до планування спортивного тренування, які повинні передбачати теоретичне опрацювання із застосуванням електронно-обчислювальних приладів основних можливих варіан- тів структури тренування 3 метою прогнозування їх ефективності і вибору найбільш оптимального [11].

Замість аналітико-системного підходу Ю. В. Верхошанський пропонує перехід до програмно-цільового підходу до організації тренування [4]. Цей принцип ґрунтується на постановці конкретних цільових завдань на тому чи іншому етапі підготовки та змагальної діяльності, що забезпечує їх реалізацію. Тренувальний процес організовується відповідно до певних цільових завдань, які конкретно виражаються в заданій величині зростання спортивного результату й обумовлюють необхідну для їх реалізації програму тренування $[9,10]$.

Виявлення оптимальної (3 точки зору досягнення найвищого спортивного результату за певний проміжок часу або іншого критерію ефективності) структури тренування і її корекцій у зв'язку з новими, непередбаченими в первинному опрацюванні, фрактами і $є$ програмуванням тренувального процесу [4, 14]. Програмування - досконаліша форма планування тренування, в його основі лежить процедура ухвалення рішення, пов'язаного з: 1) визначенням загальної стратегії підготовки спортсмена; 2) вибором оптимального варіанта побудови тренувального процесу. Таким чином, головною умовою безпомилкового вибору оптимального рішення $€$ наявність підстав для попередньої оцінки ефективності того або іншого варіанта $[4,11]$.

Програмування спортивного тренування - це планування більш високого рівня. Воно передбачає створення інформаційних банків стандартизованих тренувальних програм, а також розробку цільових завдань і стандартизованих алгоритмів для здійснення конкретних процедур планування на основі виділення структури типізації та моделювання різних за величиною циклів $[6,9,10,16]$

у процесі еволюційного розвитку методики підготовки зусиллями видатних спортсменів і тренерів поступово впроваджувалися в практику окремі елементи програмування. Було сорормульовано такі правила: відповідність тренувальних на- 
вантажень вимогам діяльності змагання; застосування високих, але доступних для спортсмена тренувальних обсягів роботи як бази для подальшої інтенсифрікації тренування; пріоритет досягнення високого рівня спеціальної фрізичної підготовленості відносно вирішення інших завдань тренування тощо. Все це зробило можливим вирішення всієї проблеми програмування тренування в цілому [11].

Учені зазначають, що логічним розвитком цих положень стало перспективно-прогностичне програмування тренувального процесу [2]. На думку Є. М. Бєлікова, комплекс програмованих засобів підготовки юних та кваліфікованих спортсменів включає такі компоненти: цільової установки, цільових завдань, засобів досягнення мети, засобів контролю, засобів корекції та сприяє віддзеркаленню специфріки їхнього вікового і спортивного онтогенезу [2].

Тренувальний процес на основі принципів програмування організовується відповідно до описаної вище цільової установки, з якої випливає ряд цільових завдань. Для реалізації завдань програмування тренування вдаються до розробки комплексних моделей спеціальної фрізичної підготовленості, заснованої на кількісних оцінках розвитку основних рухових якостей і складових окремих здібностей, що визначають рівень спортивних досягнень спорстменів 3 виявленням їх питомої ваги залежно від спеціалізації і кваліфікації, що особливо актуально для веслування на байдарках і каное [11].

Важливою складовою частиною алгоритму програмування тренувальних навантажень веслувальників $€$ забезпечення зворотного зв'язку (контролю спеціальної підготовленості), що дозволяє оцінити стан і рівень підготовленості спортсмена для внесення своєчасних коректив до розроблених програм. Це здійснюється шляхом порівняння реальних і модельних (чи спрогнозованих) показників спортивних результатів на різних дистанціях і в тренувальних контрольних заїздах. Для надійності оцінки підготовленості і виявлення причин неузгодженості проводять порівняння зареєстрованих та модельних характеристик спеціальної фрізичної підготовленості веслувальників. Таким чином, корекція тренувальних програм здійснюється на основі контролю стану спортсмена й аналізу його тренувальних навантажень, тобто даних, отриманих у результаті зворотного зв'язку. У випадках значних неузгоджень прогнозованих і реальних показників змінюється стратегія підготовки шляхом зміни методів тренування і складу тренувальних засобів при збереженні загальної динаміки комплексних показників навантаження (для корекції застосовуються моделі тренувальних програм).

у деяких наукових працях зазначається, що програмування тренувального процесу спирається на особливості рухово-технічної діяльності спортсменів, особливості календарних змагань, стратегію та закономірності процесу адаптації організму до тренувальних навантажень, їх індивідуальні особливості повязані з динамікою розвитку рухових спроможностей (темпів росту, характеру взаємозвязків та часу утримання), взаємозвязок спеціальної фрізичної та технічної підготовки [13].

На думку В. М. Костюкевича, теоретико-методичні аспекти програмування тренувального процесу мають бути обумовлені [9]:

- ієрархічною структурою, в якій менші програмні структурні утворення мають бути підпорядковані більшим (наприклад, мікроцикли мезоциклам);

- цільовими установками до програм підготовки на кожному з етапів тренувального процесу;

- загальними та спеціальними принципами підготовки спортсменів;

- алгоритмічністю - покроковим плануванням і корекцією управлінських впливів;

- плануванням співвідношення тренувальних навантажень різної спрямованості, а також засобів і методів тренувальної роботи;

- використанням адекватних критеріїв контролю на кожному з етапів тренувального циклу.
Подальша розробка питань програмування спортивного тренування передбачає фрормування теоретикометодологічних засад та застосування системного підходу до програмування підготовки кваліфікованих спортсменів (рис.1). Реалізація системного методологічного підходу у циклічних видах спорту знайшла своє відображення у роботах багатьох учених $[8,12$, 17-19, 20].

Використання системного підходу дозволило представити програмування цілісною системою, де зниження чи зростання ефективності кожного компонента має якісний вплив на ефективність системи програмування й управління тренувальним процесом веслувальників взагалі.

Застосування системного підходу дозволило науково обґрунтовано підійти до розробки, формалізації та алгоритмізації програмування відповідно до системи управління тренувальними і змагальними навантаженнями спортсменів у веслуванні та визначити шляхи його практичної реалізації в системі багаторічної підготовки веслувальників.

Під час аналізу програмування як системного компонента управління тренувальним процесом веслувальників проблемними залишаються питання структурної оптимізації спеціалізованої спрямованості контролю та моделювання $з$ урахуванням структури функціонального забезпечення спеціальної роботоздатності спортсменів залежно від тривалості та енергозабезпечення змагальної дистанції у веслуванні.

Структурна оптимізація - цілеспрямований ітераційний процес отримання серії системних ефектів 3 метою оптимізації прикладної мети в рамках заданих обмежень. Структурна оптимізація практично досягається за допомогою спеціального алгоритму структурної переорганізації елементів системи.

Отримані результати дозволили створити алгоритмізовану систему критерій-орієнтованого програмування, що складається з кількох фуннціональних блоків:

- первинний контроль з визначенням індивідуальних параметрів трену- 
Теоретичні основи

Концептуальні підходи

Системно-цільовий

Системно-елементний

Системно-функціональний

Системно-структурний

Системно-комунікаційний

\begin{tabular}{l}
$\qquad$ \\
\multicolumn{1}{|c|}{ Підсистема програмування } \\
\multicolumn{1}{c|}{ підготовки } \\
17-18-річних спортсменів \\
(юнаки і дівчата) \\
18-23-річних спортсменів- \\
веслувальників \\
кваліфікованих спортсменів- \\
веслувальників \\
$\qquad$ \\
\hline
\end{tabular}

Система управління тренувальними та змагальними навантаженнями у процесі підготовки веслувальників Система програмування підготовки веслувальників
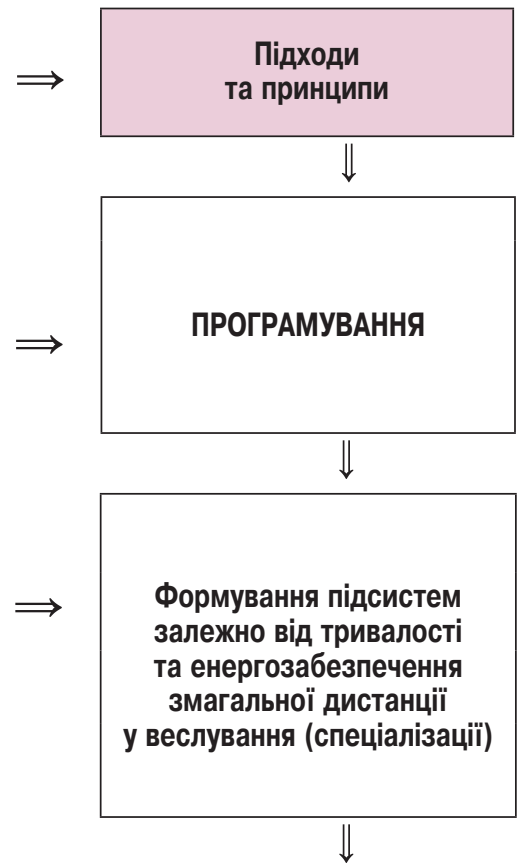

3 урахуванням статі, віку (17-18-річні, 19-23-річні, кваліфіковані спортсмени, кваліфікації, спеціалізації (академічне веслування, веслування на байдарках і каное)

Формування компонентів програмування - вибір засобів, спеціалізованої спрямованості; тестових завдань та програм тестування, моделей підготовленості та підготовки, які застосовуються, проводиться на основі аналізу кожного компонента і їх взаємозв'язку в рамках конкретної організаційної структури

Використання моделей підготовленості: узагальнені, групові, індивідуальні моделі та нормативні характеристики функціонального забезпечення спеціальної роботоздатності; моделей програм контролю для конкретного контингенту; моделі програм підготовки та тренувальних навантажень, режимів тренувальної роботи, що застосовуються для корекції тренувального процесу

Програмування - система, де зниження або зростання якості кожного компонента впливає на ефективність всієї системи


Структуризація - дозволяє аналізувати елементи системи та їх взаємозв'язку $\Leftrightarrow \quad$ в рамках конкретної організаційної структури

Множинність - дозволяє використовувати множину моделей для опи-

$\Leftrightarrow \quad$ су окремих елементів та системи в цілому

Системність - наявність ознак систе-

\section{$\Downarrow$}

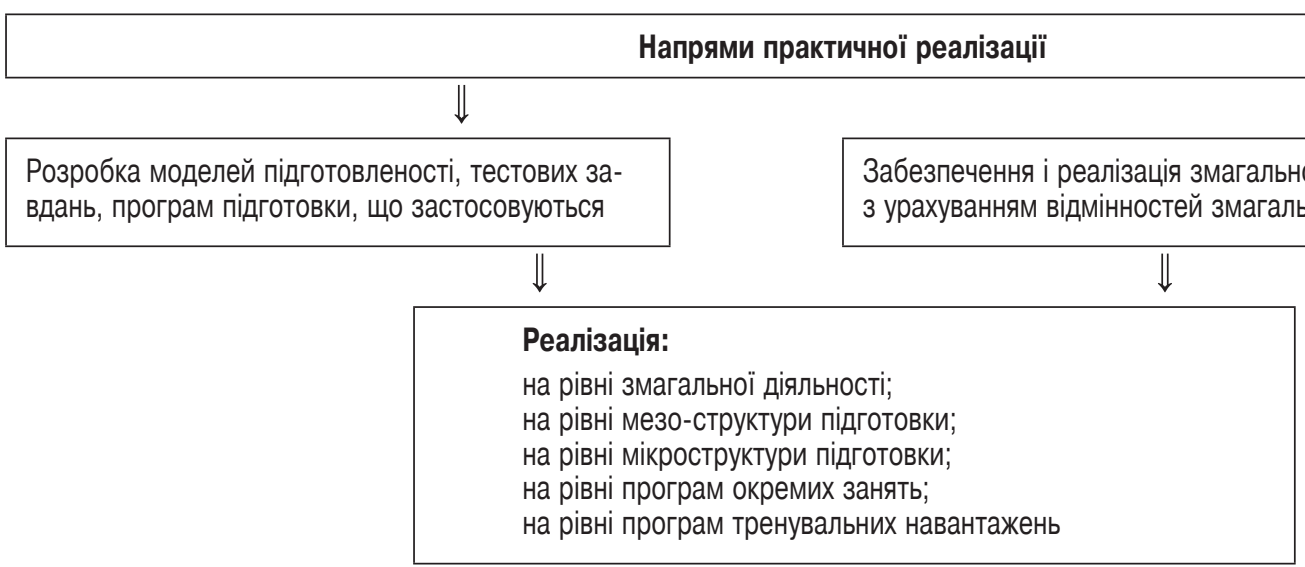

Рисунок 1 - Система програмування підготовки веслувальників (складено за результатами досліджень автора) 


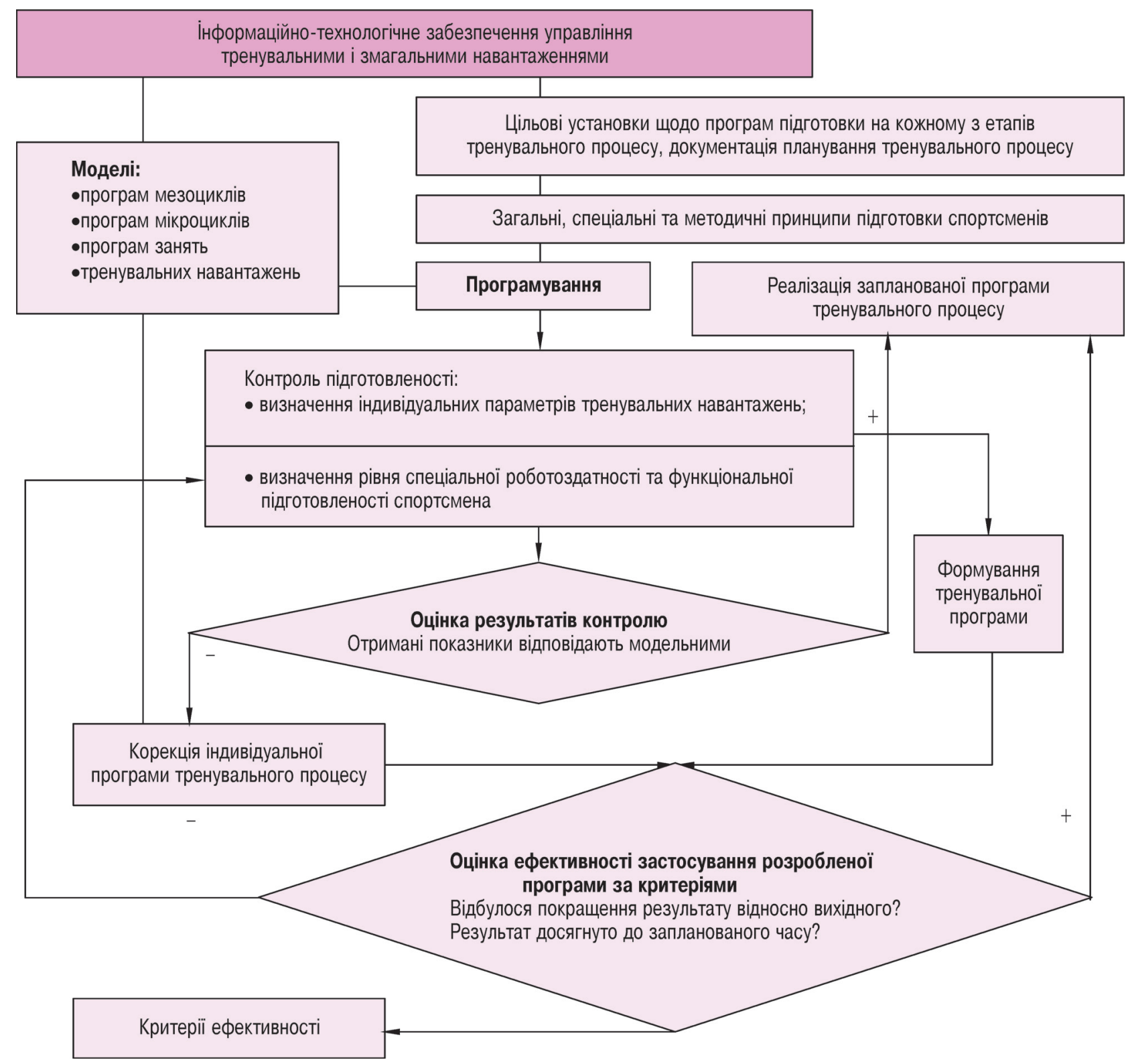

Рисунок 2- Алгоритм програмування тренувальних навантажень у процесі підготовки кваліфрікованих спортсменів у веслуванні (складено за результатами досліджень автора)

вальних навантажень; рівня спеціальної роботоздатності та функціональної підготовленості спортсмена на певному етапі тренувального процесу;

- формування тренувальної програми для визначеного періоду з урахуванням індивідуальних параметрів навантаження спортсмена;

- оцінювання результатів контролю та визначення відповідності отриманих показників модельним;

- корекція завдань тренувальної програми в разі неповної реалізації програми попереднього періоду. В результаті програма піддається корекції, що найчастіше виражається у допо- вненні завдань нового періоду невиконаними завданнями попереднього;

- проведення комплексу тренувальних заходів на основі скоригованої програми;

- оцінка ефективності застосування розробленої програми, аналізу досягнутих критеріїв;

- оцінка ефективності застосування розробленої програми. Рух циклу закінчується тоді, коли оцінка результатів контролю відповідає встановленим вимогам.

На рисунку 2 схематично зображено алгоритмічну послідовність дій критерій-орієнтованого програмуван- ня у процесі підготовки кваліфікованих спортсменів у веслуванні.

Компонети управління тренувальним процесом веслувальників $€$ взаємозалежними елементами системи від ефективності функціонування одного компонента залежить ефективність інших. Взаємопов'язані програмування та контроль із системою відбору й орієнтації спортсменів у процесі багаторічної підготовки; програмування із системою моделювання й прогнозування; із системою планування у різних структурних утвореннях річного циклу підгототовки; із системою тренувальних засобів, зокрема 3 
формуванням методичних підходів до вибору спеціалізованої спрямованості тренувального процесу, його індивідуалізації, вибору засобів і методів тренування, параметрів вправ і режимів роботи. Окремі теоретичні аспекти реалізації цього підходу систематизовані й представлені у сучасній літератуpi $[8,14,19]$.

Дискусія. Викладений аналіз літературних джерел дозволяє стверджувати, що проблема побудови тренувального процесу спортсменів на основі програмування нині $€$ актуальною [4, 9, 10, 14]. Проте, досить не повно та фррагментарно представлені дані про особливості програмування тренувальних навантажень у процесі підготовки кваліфікованих спортсменів у веслуванні. Потребують наукового обґрунтування теоретикометодичні основи цілісного системноконцептуального підходу до розробки програм структурних утворень тренувального процесу (тренувальних завдань і занять, логічної блок-схеми мікроциклів, програм окремих структурних утворень) кваліфрікованих веслувальників. Актуальними залишаються питання експериментального підтвердження дієвості механізму практичної реалізації програмування тренувального процесу кваліфікованих веслувальників.

Актуальними питаннями під час розробки алгоритму програмування режимів тренувальних занять залишається систематизація тренувальних засобів, що використовуються у процесі підготовки веслувальників, та створення відповідної класифрікації. В основу цієї розробленої класифріцикації має бути покладена ознака спеціалізованості, за якою об'єднані змагальні і спеціально-підготовчі вправи, що використовуються у процесі підготовки веслувальників.

Тренувальні засоби, згруповані 3 урахуванням методів тренування і спеціалізованої спрямованості, стануть відповідною складовою інформаційно-технологічного забезпечення управління тренувальними змагальними навантаженнями. Як зазначає В. М. Платонов, інформаційне забезпечення - одна 3 важливих функцій, що визначають обґрун- тованість управлінських рішень, що дає можливість виокремити зовнішнє інорормаційне забезпечення - обсяг знань та практичного досвіду, що дозволяє досягти високого рівня наукового та організаційно-практичного рівня управління: сформулювати мету і завдання, розробити моделі, систематизувати засоби і методи, забезпечити процес планування і контролю тощо [14]

Вирішення цієї наукової проблеми створить передумови для більш ефективного управління тренувальним процесом кваліфрікованих веслувальників на основі створення моделей тренувальних навантажень спрямованої дії, а також конкретизації структури та організації процесу підготовки у різних структурних утвореннях річного циклу підготовки.

Висновки. Основні теоретичні здобутки та розроблені підходи до програмування (аналітико-системний; програмно-цільовий; перспективно прогностичний) посідають важливе місце в арсеналі сучасної теорії та методики спортивної підготовки.

Аргументовано, що система програмування відзначається цілісністю $€$ складно організованою, ієрархічно впорядкованою сукупністю елементів, поєднаних між собою зв'язками, які $€$ результатом взаємного впливу окремих складових. У системі програмування обгрунтовані шляхи практичного застосування та реалізації ї у процесі підготовки кваліфікованих спортсменів у веслуванні.

Перспективи подальших досліджень полягають у практичній реалізації розробленої система програмування підготовки веслувальників.

Конфлікт інтересів. Автор заявляє що відсутній будь-який конфлікт інтересів.

\section{ЛITEPATУРA}

1. Баканов МВ. Программирование тре нировочного процесса конькобежцев высокой квалификации с учетом факторной структу ры подготовленности [автореферат]. Москва 2005. 23 .

2. Беліков ЄM. Програмування підготовки юних кваліфікованих боксерів [авторефрерат] Москва, 2004. 22.

3. Верхошанский ЮВ. Теоретико-методи ческие подходы к реализации идеи управления тренировочными процессами. Теория и практика фризической культуры. 1981; 4: 8-11.
4. Верхошанский ЮВ. Программирование и организация тренировочного процесса. Москва: Физкультура и спорт, 1985. 239.

5. Врублевский ЕП. Теоретико-методическое обоснование программирования макроцикла подготовки спортсменок, специализирующихся в скоростно-силовых видах легкой атлетики. Слобожанський науково-спортивний вісник. 2011; 4: 74-77.

6. Гордон СМ. Спортивная тренировка: науч.-метод. пособие. Москва: Физическая культура, 2008. 256

7. Горлов АС. Програмування тренувального процесу юнаків-спринтерів у відновлювальних мікроциклах підготовчих періодів [автореферат]. Київ, 1994. 24.

8. Дьяченко АЮ. Совершенствование специальной выносливости квалифицированных спортсменов в академической гребле. Киев: НПФ «Славутич-Дельфин», 2004. 338.

9. Костюкевич В. Теоретико-методичні аспекти програмування тренувального процесу спортсменів. Актуальні проблеми фізичного виховання та методики спортивного тренування, 2016. 138-142.

10. Костюкевич В, Стасюк В. Програмування тренувального процесу кваліфікованих футболістів у річному макроциклі. Фізична культура, спорт та здоров'я нації. 2016; 1: 323331.

11. Кулаков ВН. Программирование тренировочного процесса высококвалифицированных бегунов на средние, длинные и сверхдлинные дистанции [автореферат]. Москва, 1995. 48.

12. Мищенко ВС. Эргометрические тесты и критерии интегральной оценки выносливости. Спортивна медицина. 2005; 1: 42-52.

13. Никитушкин ВГ. Спорт высших достижений. Теория и методика [Электронный ресурс]: учебное пособие. Электрон. текстовые данные. Москва: Издательство «Спорт», 2018: 320.

14. Платонов ВН. Система подготовки спортсменов в олимпийском спорте. Общая теория и ее практические приложения: учебник: Киев: Олимпийская лит.; 2015. 2 т.

15. Фискалов ВД, Черкашин ВП. Теоретические основы подготовки спортсменов. Волгоград, 2006. 245.

16. Bompa TO. Total training for coaching team sport. Toronto: Sport books publisher, 2006

17. Buchheit M, Laursen P. High-Intensity Interval Training, Solutions to the Programming Puzzle: Part II: Anaerobic Energy, Neuromuscular Load and Practical Applications. Sports medicine. 2013.

18. Haff Guy. Quantifying Workloads in Resistance Training: A Brief Review. Prof. Strength and Cond. 2010; 10: 31-40.

19. Mishchenko V, Suchanowski A. Athlete's endurance and fatigue characteristics related to adaptability of specific cardiorespiratory reactivity. Gdansk : AWFIS; 2010: 176.

20. Tomiak T. Teoretyczno-metodyczne podstawy doskonalenia wytrzymałości specjalnej wioślarzy klasy mistrzowskiej. Gdańsk : Wydawnictwo Uczelniane AWFiS; 2008: 252

\section{LITERATURE}

1. Bakanov MV. Programming of the training process of highly qualified skaters with account for the factor structure of fitness [author's abstract]. Moscow, 2005. 23. 
2. Belikov IM. Programming preparation of young skilled boxers [author's abstract]. Moscow, 2004. 22.

3. Verkhoshansky YV. Theoretico-methodical approaches to realization of the idea of training process management. Teoriya i praktika fizicheskoy kultury. 1981; 4: 8-11.

4. Verkhoshansky YV. Training process programming and organization. Moscow: Fizkultura i sport, 1985. 239.

5. Vrublevsky EP. Theoretico-methodical substantiation of programming preparation macrocycle of female athletes specialized in speed strength events of track and field. Slobozhanskyi naukovosport. visnyk. 2011; 4: 74-77.

6. Gordon SM. Sports training: instructional guide. Moscow: Fizicheskaya kultura, 2008. 256.

7. Gorlov AS. Programming training process of young sprinters in recovery microcycles of preparatory periods [author's abstract]. Kyiv, 1994 24.

8. Dyachenko AY. Improving special endurance of skilled rowers. Kiev: NPF «Slavutych-Delfin», 2004. 338.

9. Kostiukevych V. Theoretico-methodical aspects of training process programming. Aktualni problem fizvykhovania ta metodyky sportyvnoho trenuvannia, 2016. 138-142.

10. Kostiukevych V, Stasiuk V. Programming of training process of skilled footballers in annual macrocycle. Fizychna kultura, sport ta zdorovia natsii. 2016; 1: 323-331.
11. Kulakov VN. Programming of training process of highly skilled middle, long and super long distance runners [author's abstract]. Moscow, 1995. 48.

12. Mishchenko VS. Ergometric tests and criteria of endurance integral assessment. Sportyvna medytsyna. 2005; 1: 42-52.

13. Nikitushkin VG. Elite sport. Theory and methods [Electronic resource]: teaching guide. Moscow: Izdatelstvo «Sport», 2018: 320.

14. Platonov VN. System of athletes' preparation in the Olympic sport. General theory and its practical applications: textbook. Kiev: Olimpiyskaya literatura; 2015. 2 Vol.

15. Fiskalov VD, Cherkashin VP. Theoretical bases of athletes' preparation. Volgograd, 2006. 245 .

16. Bompa T0. Total training for coaching team sport. Toronto: Sport books publisher, 2006.
17. Buchheit M, Laursen P. High-Intensity Interval Training, Solutions to the Programming Puzzle: Part II: Anaerobic Energy, Neuromuscular Load and Practical Applications. Sports medicine. 2013.

18. Haff Guy. Quantifying Workloads in Resistance Training: A Brief Review. Prof. Strength and Cond. 2010; 10: 31-40.

19. Mishchenko V, Suchanowski A. Athlete's endurance and fatigue characteristics related to adaptability of specific cardiorespiratory reactivity. Gdansk : AWFIS; 2010: 176

20. Tomiak T. Teoretyczno-metodyczne podstawy doskonalenia wytrzymałości specjalnej wioślarzy klasy mistrzowskiej. Gdańsk : Wydawnictwo Uczelniane AWFiS; 2008: 252.

Надійшла 16.06.2020

\section{ІНФОРМАЦІЯ ПРО АВТОРА}

Русанова Ольга Михайлівна https:orcid.org/ 0000-0001-7495-7030, rusanova2080@gmail.com Національний університет фізичного виховання і спорту України, 03150, Київ, вул. Фізкультури, 1

\section{INFORMATION ABOUT THE AUTHOR}

Rusanova Olga https:orcid.org/0000-0001-7495-7030, rusanova2080@gmail.com National University of Ukraine on Physical Education and Sport, 03150, Kyiv, Fizkul'tury str., 1. 